\title{
Engaging Early Childhood Learners of EFL through Balinese Folklore Picture Books during Distance Learning in Singaraja Bali
}

\author{
I Putu Yoga Purandina ${ }^{1 *}$ and Gusti Ayu Putu Diah Permata Sari $\mathrm{AR}^{2}$
}

\author{
${ }^{I}$ Early Childhood Teacher Education, Dharma Acarya Department, Sekolah Tinggi Agama Hindu Negeri Mpu \\ Kuturan Singaraja, Singaraja, Bali 81119, Indonesia \\ ${ }^{2}$ Communication Sciences, Dharma Duta Department, Sekolah Tinggi Agama Hindu Negeri Mpu Kuturan Singaraja, \\ Bali 81119, Indonesia \\ *Corresponding author. Email: yogapurandina@gmail.com
}

\begin{abstract}
Balinese folklore is an attractive English learning medium for children. During distance learning, in several kindergartens in Singaraja, the teachers provided illustrated storybooks to children, in the form of Balinese folklore as reading material at home for the introduction of English as a foreign language. This study aims to describe the stages of introducing English to early childhood through Balinese folklore Picture Books during distance learning in Singaraja, Bali. As well as describing how early childhood vocabulary development in the introduction of English as a foreign language through Balinese Folklore Picture Books during distance learning in Singaraja Bali. The research was designed using a qualitative approach. The data was the children in three kindergartens in Singaraja Bali, amounting to 34 children who were taken randomly. Supporting data is also obtained from the teachers and parents of the child as additional data. The data were collected through observation, interview, and questionnaire then analyzed qualitatively. The result showed that the stages of introducing English as a foreign language were initiated by compiling a weekly learning plan containing collaborative activities between children and parents. By giving Balinese Folklore picture books written in English, both printed and digital. Then given training in the form of matching pictures with vocabulary, mentioning story characters, and finding moral values that can be taken from the stories. The development of children's vocabulary in English can develop properly where children were able to mention some vocabularies in English and also children are motivated to increase their enthusiasm for learning English during distance learning.
\end{abstract}

Keywords: early childhood learners, EFL, Balinese folklore, picture books, distance learning

\section{INTRODUCTION}

English lesson is one of subject which can be delivered in early childhood education school level. In this stage, the children started to learn four basics English skills included speaking, reading, listening, and writing [1]-[3]. There were many English activities created by the teacher to stimulate the students' motivation during English lesson. As well as, the condition during COVID-19 Pandemic encourage the English teacher to adapt and innovates English learning material which appropriate with the situation and condition [4].

During the COVID-19 pandemic, there were obstacles in the introduction of English to early childhood [5], [6]. Activities carried out remotely cause various obstacles such as the difficulty of finding the right method of introducing English, choosing media that can be flexible to be carried out remotely, then good and effective communication between teachers, parents, and children [7], [8]. So the teacher at a time like this must be able to be creative. Being selective and effective in choosing and designing an activity that is still able to provide fun activities and of course can improve children's English skills [9].

Blended learning is inevitable in this distance learning. The teacher must be able to conduct an initial analysis in determining the approach to the activities to be carried out [10], [11]. What and how the needs, and environmental conditions of their children. So the online approach is the main choice combined with the offline approach. This combination is still a good choice for now in Indonesia, especially in Bali. Technical constraints will be able to find the right solution because 
there has been a blended learning approach, namely online and offline [12].

Although various obstacles are faced in recognizing English, this activity must be carried out because it is very important to introduce literacy, especially in English for children. Children should be given introductions to English literacy to increase their ability in literacy and verbal communication [13]. In addition, children also need to be given fun activities that can develop children's language skills. Language is included in six aspects of early childhood development such as religious and moral values, physical-motor, cognitive, language, socio-emotional, and art [14]. However, this fun activity should be done collaboratively.

English teaching and learning in kindergarten area can be taught by enjoyable activities. This based on students' characteristic as toddler. Toddler defined as children start from 1-4 years old. In this period, toddler may be introduced by literacy session. In this case, the teachers are expected to be able to introduce folklore as one of learning material during literacy session [15], [16]. Folklore defined as story which contains the tradition, custom, and believed inherited to next generation. There were many moral values that used as guidance in the daily life [17].

Story in this case folklore is still a good medium for the introduction and development of language, especially English for children [18], [19]. Language skills, vocabulary, and good communication will develop well according to their age development. In addition, stories, especially folklore, will provide a moral education through the moral values contained in them [20]. Cultural introduction is also an emphasis in learning English through folklore. Culture as an identity, namely the character itself provides a noble personality for children in interacting in their environment [21].

Then folklore also acts as a medium for delivering messages, a means of building inner contact, developing imagination, and as a medium for children's entertainment [22]. Children are given a collaborative sensation in learning and playing. So that folklore is a tasty medium for children, but must still be adapted to the times [23]. The appearance or packaging of course must change from time to time. Not just conventionally. Hearing the word folklore will certainly imagine something ancient. Ancient and unwritten regional tales that were only told by word of mouth. This appearance must change so that it will become more attractive and contemporary according to the current generation of children [24].

There were various kinds of folklore in Indonesia. Especially in Bali, folklore became the main attraction for children. Balinese parents usually told the story during the spare time and bedtime [25], [26]. The children would be learnt the new word when they heard the story. Unconsciously, the children were able to enrich their vocabulary during this activity. This statement is supported with the research by Ismail, Samad, and Masnur in 2019 who explained through folktales, the young language learners are exposed to wide range of authentic vocabulary. In this case, the children had opportunity to explore the vocabulary which can be used in the daily communication [27].

Moreover, folklore was not only delivered by oral tradition, but also delivered by literacy through writing and reading. In this case, the children could find folklore from picture books. The picture book is a book that has content of drawing and text [28]. The picture books are believed to increase children enthusiasm during learning process. The language developments also grow optimally because stories showed in the picture books would stimulate the children to understand the unfamiliar language. Besides, the pictures displayed in picture books are illustration or cartoon that suitable with the story. Thus, the children felt more interesting and focus to read the story independently.

As research conducted by Nanda et al in 2021 on folklore originating from Central Java provides good character education and can improve children's language skills. Cultivate personality values in accordance with local characters [29]. Indonesia, which consists of various ethnic groups, certainly has its own folklore and is adapted to local wisdom in each of these areas. As research conducted by Anisa in 2019 provides extensive reading which is good for children's literacy development, as an authentic medium that can stimulate children's development, especially in English development [30]. Then to answer the development of the era of research by Widhiyanti in 2021, the introduction of stories or folklore to children can be done in various media variations such as story books, video stories, and puppets, but packaged digitally which is up to date [31].

In this research, the researcher used Balinese Folklore Picture Books to improve students' English skill in kindergarten area during distance learning. There were six stories displayed in the picture books. Those stories are written in English both printed and digital. Besides, parents had important roles during this activity. They should accompany their children in reading the story. It was useful to monitor the children language development during the reading session. In addition, this activity could strengthen the relationship between parents and children. Thus, the process of learning English as second language will be successful and gave positive impact for children in the future.

\section{METHOD}

The research design used in this study is qualitative research. Qualitative research focuses on investigating the quality of relationships, activities, sites, and materials [32]. This research is a qualitative descriptive study in which the setting, place, condition, and situation are direct data, and the researcher has a central role as a key to all existing instruments (Key Instrument) [33]. Furthermore, this qualitative descriptive research is very suitable for investigating certain people, events, groups of people, and institutions. 
This research was conducted in several PAUD schools in Singaraja City, which during the COVID-19 pandemic continued to introduce and develop English for early childhood. At several PAUD schools in the city of Singaraja, activities were carried out to provide folklore stories to children through distance activities. The teacher gives Balinese folklore stories in the form of picture story books that are provided online or offline. The school designed this activity according to the weekly lesson plan for the COVID-19 Pandemic emergency.

Sources of data sought in this study were written data and oral data. The primary data obtained is a weekly lesson plan designed by PAUD teachers in introducing English remotely. Especially in the activity of giving Balinese Folklore Picture Book to children. What are the steps of activities, activities that must be done by children and parents at home? There were 34 children and their parents who were interviewed to find out the activities and development of English for early childhood. Secondary data was also obtained in the form of characteristics of Balinese Folklore and local wisdom of Balinese Culture as a reinforcement for the impact of using local Balinese folklore media.

Researchers are the key instrument in this study, where researchers with their understanding and instincts in analyzing the data obtained [34]. Then the main instruments are observation sheets, interview lists, and questionnaires. Observation sheets are used to obtain data regarding the steps of activities carried out according to the lesson plan and to determine the interaction of children and parents in activities. Questionnaires are used to obtain data on the development of English for early childhood during the distance learning of the COVID-19 pandemic. Then interviews were used to obtain additional data in the form of confirmation of the activities designed by the teacher, as well as how the children and parents felt about this activity and the development of their children's English.

In this research, of course, triangulation and trustworthiness data have been applied. All instruments used in this research are appropriate and appropriate instruments for conducting qualitative descriptive research methods. Indeed, to achieve research objectives like this must be assisted by instruments in observing and obtaining data [35], [36]. To get the right and appropriate data, reliable and valid data must be obtained. The data obtained must be cross-checked and repeated to find valid data that is often referred to as Data Triangulation [37]-[39]. Campbell and Fiske add that triangulation is an approach or way to obtain accurate data using different data collection strategies or combinations [40]. In addition, trustworthiness data is also carried out in this study, focusing on fouraspects: data, data transcription, data collection techniques, and findings.

Data analysis was carried out based on the MilesHuberman approach, which consists of three concepts, namely data reduction, which has been carried out directly at the time of data collection, second is the presentation of data (Data Display), and verification of conclusion drawings [41], [42]. This analytical approach is an activity that is directly involved in the investigation process. Once the data is obtained, it will be directly analyzed as a form of the investigation process. Analyzing the data is carried out interactively and simultaneously until all problems in this research are answered, or a solution is obtained. Data reduction is made very carefully where only the necessary data is taken according to the problem research.

\section{FINDING \& DISCUSSION}

\subsection{Stages of Engaging Early Childhood Learners of EFL through Balinese Folklore Picture Books}

In accordance with the research question in this study, findings were obtained regarding the stages of engaging in early childhood learners of EFL through Balinese Folklore. This finding is found through the process of observing the lesson plan, the stages of activities contained in the lesson plan. Indeed, in some PAUD schools there are differences in the number and types of stages. But overall there are similarities in the pattern given by the teacher.

The stages of this activity are 1) the teacher chooses a Balinese folklore picture book, either online or printed. 2) The teacher designs the activities to be carried out by pouring it into the lesson plan. 3) The teacher gives Balinese folklore picture book. 4) The teacher communicates with parents and children regarding activities and activity steps. 5) Parents and children carry out collaborative activities, carry out activities by reading, looking for difficult vocabulary, and looking for the moral values contained in it. 6) Thorough evaluation by monitoring the child's activity in doing some exercises.

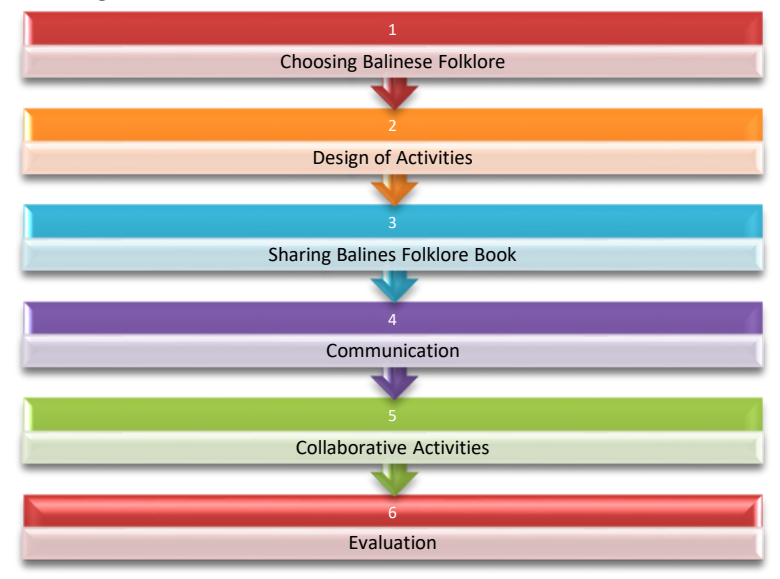

Figure 1. Stages of Engaging Early Childhood Learners of EFL through Balinese Folklore Picture Books

In this first stage, the teacher chooses the Balinese folklore Picture Book which is already in English and is indeed suitable to be given as supplementary reading for early childhood [43]. Although you still have to be accompanied by parents, this book is recommended for early childhood. There are six books used after in-depth 
observations and interviews. The books are The Black Hen, The Legend of Singaraja, Kebo Iwa and Lake Batur, Manik Angkeran, Pan Balang Tamak, and I Belog. Where all these stories are original Balinese folklore stories packaged into picture book stories. Some of these books are found in both online and printed form.

In the second stage, the teacher plans activities by making weekly lesson plans. This activity is carried out once a week to two weeks. So the activities arranged in this series of activities are not just reading story books but reading books, searching and finding vocabulary that has been determined by the teacher, and finding the moral message conveyed by the story. Within a week or two, children will be given one Balinese folklore picture book, then given activities to read with their parents, find vocabulary and match words with pictures on the exercise sheet, color the pictures, and imitate the sounds in the exercises.

The third stage is to distribute or give a book or link to the Balinese folklore picture book to parents through a Whatsapp group containing parents and teachers. Because there are online and offline activities, this stage is carried out flexibly according to media sources or the Balinese folklore picture book itself.

Then in stage four, the teacher communicates with the child and the parents. The communication that is built is a two-way communication where children and parents are given the opportunity to provide input on this activity. So the teacher's role is to explain clearly the steps of the activity and accommodate input by parents by accommodating the wishes of the child. Because the main purpose of this activity is fun learning.

The fifth stage is the core activity, collaborative activities of parents and children carried out at home. Parents and children together access the Balinese folklore picture book given by the teacher. Parents and children make the reading process fun by paying attention to the pictures. Then there are activities such as exercises in finding vocabulary, matching words with pictures, coloring words or pictures, imitating words in English. In addition, parents must provide or convey the moral message contained in the story.

The sixth stage is the evaluation activity, where the teacher monitors the results of the exercises carried out by the children accompanied by their parents at home. In addition, the teacher will carry out further communication with parents regarding the development of their children. Parents are also required to send videos on some of the activities included in this activity. So that teachers can see the development of children's English Vocabulary skills.

\subsection{The Development of Children's English Vocabulary}

Finding about the development of children's English vocabulary by doing the Engaging Early Childhood Learners of EFL through Balinese Folklore Picture Books activity is very good. Although still at the introduction stage, this activity shows a positive progress in the development of children's English vocabulary. The finding obtained is quality finding through the process of filling out a questionnaire, observation, and interviews with parents and teachers.

Table 1. Progression level of English Vocabulary Development

\begin{tabular}{|c|c|c|c|c|c|}
\hline \multirow{2}{*}{$\begin{array}{c}\text { Vocabularies } \\
\text { Development Criteria }\end{array}$} & \multicolumn{5}{|c|}{ Progression levels } \\
\hline & 11 & 22 & 33 & 44 & 55 \\
\hline $\begin{array}{l}\text { Children are able to } \\
\text { recognize English } \\
\text { vocabulary }\end{array}$ & $\begin{array}{c}15.88 \\
\%\end{array}$ & $\begin{array}{c}214.71 \\
\%\end{array}$ & $\begin{array}{c}541.18 \\
\%\end{array}$ & $\begin{array}{c}823.53 \\
\%\end{array}$ & $\begin{array}{c}214.71 \\
\%\end{array}$ \\
\hline $\begin{array}{l}\text { Children are able to } \\
\text { match words with } \\
\text { pictures }\end{array}$ & $\begin{array}{c}22.94 \\
\%\end{array}$ & $\begin{array}{c}217.65 \\
\%\end{array}$ & $\begin{array}{c}447.06 \\
\%\end{array}$ & $\begin{array}{c}220.59 \\
\%\end{array}$ & $\begin{array}{c}111.76 \\
\%\end{array}$ \\
\hline $\begin{array}{l}\text { Children are able to } \\
\text { complete the letters in } \\
\text { the word gap }\end{array}$ & $\begin{array}{c}111.76 \\
\%\end{array}$ & $\begin{array}{c}114.71 \\
\%\end{array}$ & $\begin{array}{c}447.06 \\
\%\end{array}$ & $\begin{array}{c}117.65 \\
\%\end{array}$ & $\begin{array}{c}88.82 \\
\%\end{array}$ \\
\hline $\begin{array}{l}\text { Children are able to } \\
\text { color pictures that are } \\
\text { ordered according to } \\
\text { English vocabulary }\end{array}$ & $\begin{array}{l}00 \\
\%\end{array}$ & $\begin{array}{c}220.59 \\
\%\end{array}$ & $\begin{array}{c}552.94 \\
\%\end{array}$ & $\begin{array}{c}114.71 \\
\%\end{array}$ & $\begin{array}{c}114.71 \\
\%\end{array}$ \\
\hline $\begin{array}{l}\text { Children are able to } \\
\text { associate words in } \\
\text { stories with their } \\
\text { experiences }\end{array}$ & $\begin{array}{c}229.41 \\
\%\end{array}$ & $\begin{array}{c}332.35 \\
\%\end{array}$ & $\begin{array}{c}332.35 \\
\%\end{array}$ & $\begin{array}{c}55.88 \\
\%\end{array}$ & $\begin{array}{l}00 \\
\%\end{array}$ \\
\hline $\begin{array}{l}\text { Children are able to } \\
\text { imitate (pronounce) } \\
\text { words in English } \\
\end{array}$ & $\begin{array}{c}330.30 \\
\%\end{array}$ & $\begin{array}{c}333.33 \\
\%\end{array}$ & $\begin{array}{c}227.27 \\
\%\end{array}$ & $\begin{array}{c}99.09 \\
\%\end{array}$ & $\begin{array}{l}00 \\
\%\end{array}$ \\
\hline $\begin{array}{l}\text { Children is able to show } \\
\text { the words that are } \\
\text { mentioned }\end{array}$ & $\begin{array}{c}223.53 \\
\%\end{array}$ & $\begin{array}{c}435.29 \\
\%\end{array}$ & $\begin{array}{c}223.53 \\
\%\end{array}$ & $\begin{array}{c}111.76 \\
\%\end{array}$ & $\begin{array}{c}55.88 \\
\%\end{array}$ \\
\hline $\begin{array}{l}\text { Children understand the } \\
\text { title of the story }\end{array}$ & $\begin{array}{c}111.76 \\
\%\end{array}$ & $\begin{array}{c}111.76 \\
\%\end{array}$ & $\begin{array}{c}223.53 \\
\%\end{array}$ & $\begin{array}{c}229.41 \\
\%\end{array}$ & $\begin{array}{c}223.53 \\
\% \\
\end{array}$ \\
\hline
\end{tabular}

From the table above, it is known that there is indeed an increase in the ability to recognize English which is classified from level 1-5. Level 1 is the slowest development, where the child can only perform a few actions that are ordered in each activity. Level 2 is slow progression, better than level 1 but still progressing slowly. Children are only able to do $2 / 5$ or $40 \%$ of all activities. Then level 3 is middle development, where children are able to do $3 / 5$ or $60 \%$ of activities well. Level 4 is fast development, where children are able to complete activities according to the criteria of $4 / 5$ of the total activity or about $80 \%$. Then level 5 is the highest level, where the child is able to complete all activities related to English vocabulary well or $100 \%$.

The criteria used are related to the child's ability to carry out activities that are adapted to the development of English vocabulary for children. Of course, it is also associated with the Engaging Early Childhood Learners of EFL through Balinese Folklore Picture Books during Distance Learning activity. The first criterion is that Children are able to recognize English vocabulary. Children are able to recognize English vocabulary, distinguish between Indonesian and Balinese vocabulary. The second criterion is that Children are able to match words with pictures, where children are able to match words with pictures. So that the child can understand the meaning or meaning of the word. The 
third criterion is Children are able to complete the letters in the word gap. Children are able to add letters to words that are still incomplete. Fourth criterion Children are able to color pictures that are ordered according to English vocabulary. Children are able to color pictures or letters related to English vocabulary. The fifth criterion Children are able to associate words in stories with their experiences. Children are able to associate the words in the story with experiences they have had before. The sixth criteria Children are able to imitate (pronounce) words in English. Children are able to imitate or say words in English well, imitate sounds well. The seventh criterion is that children are able to show the words that are mentioned. The child understands the word that is called and points to the word. The last criterion is children understand the title of the story. Children are able to say the title and understand the meaning of the title of the story in Balinese folklore Picture Books.

In the table it can be seen that in the first criterion as many as $5.88 \%$ of children have been able to show level 1 development, $14.71 \%$ of children have been able to level 2, 41.18 indicate level 3, 23.53\% indicate level 4 , then 14.71 indicate level 5 . So of all children the data taken in general is more at level 3, namely children are in middle development, which means $3 / 5$ or $60 \%$ of children have recognized English vocabulary well, and are able to distinguish between Indonesian vocabulary.

The second criterion shows $2.94 \%$ at level $1,17.65$ at level 2, $47.06 \%$ at level 3, 20.59\% at level $4,11.76 \%$ at level 5. Almost similar to the first criterion where children show more development at level 3. So that more children are able to match words in English with pictures well or are able to do $60 \%$ of the total wordmatching activities with pictures well.

In the third criterion, $11.76 \%$ of children have shown level 1, $14.71 \%$ are at level 2, $47.06 \%$ are at level $3,17.65 \%$ are at level $4,8.82 \%$ are at level 5 . Almost the same as criteria 1 and 2 , in criterion 3 , there are also more children who show middle development. That is as much as $47.06 \%$ were able to fill in the letters in the word gaps well and were able to complete $60 \%$ of the activities to fill in the letters in the word gaps correctly.

The fourth criterion shows $0 \%$ at level 1, 20.59\% at level 2, 52.94\% at level 3,14.71\% at level 4 , and $14.71 \%$ at level 5 . In this criterion, no children showed level 1 because Most of the children have been able to complete this drawing activity. Indeed, there are still many children showing level 3 . Children have been able to color in relation to the vocabulary in the exercise well.

In criterion five, $29.41 \%$ is still at level 1, 32.35\% indicates level 2, 32.35 indicates level 3, 5.88\% indicates level 4 , and $0 \%$ indicates level 5. Judging from this data, in this activity there are still few children who can achieve fast development or level 4. None of them even reached level 5. The children still had difficulty in relating the vocabulary in the story to the experiences they had before.
In the sixth criterion, $30.30 \%$ of children are still at level $1,33.33 \%$ are at level $2,27.27 \%$ are at level 3, $9.09 \%$ are at level 4 , and $0 \%$ are at level 5. Most children are at a low level of 1,2 , and 3 . This shows that the child still has difficulty in spelling or imitating words in English well.

In criterion seven, $23.53 \%$ of children are still at level $1,35.29 \%$ are at level $2,23.53 \%$ are at level 3, $11.76 \%$ are at level 4 , and $5.88 \%$ are at level 5. low development of the child to show the randomly mentioned word. Children are still not able to hear and understand well every word that is mentioned.

Criterion eight shows $11.76 \%$ is at level $1,11.76 \%$ is at level 2, 23.59\% is at level 3,29.41\% is at level 4, $23.59 \%$ is at level 5 . Here it is rather evenly distributed, so at each level it is almost equal. Indeed, to understand the title requires help from parents, so that children better understand the title of this story.

\section{CONCLUSION}

The obstacle to introducing English to early childhood during the COVID-19 pandemic has caused several limitations. So that in the city of Singaraja Bali, several PAUD schools provide engaging activities for early childhood learners of EFL through Balinese folklore picture books during distance learning. This activity showed a positive result. Children are given several Balinese folklore picture books which are updated every week. Then also provide collaborative activities that parents and children can do at home. The development of knowledge of English vocabulary has also increased, although not significantly but has shown positive things. Moreover, children and parents can do fun activities and can motivate children.

\section{REFERENCES}

[1] S. Sumihatul Ummah, "The Implementation of TPR (Total Physical Response) Method in Teaching English for Early Childhood," vol. 58, pp. 421-428, 2017, doi: 10.2991/icece-16.2017.74.

[2] B. Redondo, R. Cózar-Gutiérrez, J. A. GonzálezCalero, and R. Sánchez Ruiz, "Integration of Augmented Reality in the Teaching of English as a Foreign Language in Early Childhood Education," Early Child. Educ. J., vol. 48, no. 2, pp. 147-155, 2020, doi: 10.1007/s10643-019-00999-5.

[3] N. Z. Hendi and A. Asmawi, "Preschool English Teachers' Practices and Early Literacy Instruction: Montessori vs. International Preschool Curriculum.," Malaysian Online J. Educ. Sci., vol. 6, no. 2, pp. 29-36, 2018.

[4] V. N. Tarrayo and A. G. Anudin, "Materials development in flexible learning amid the pandemic: perspectives from English language teachers in a Philippine state university," Innov. Lang. Learn. Teach., pp. 1-12, Jun. 2021, doi: 10.1080/17501229.2021.1939703.

[5] A. Mustadi, P. Education, and U. Negeri, "Blended learning innovation of social media based active English during the COVID-19 pandemic," 
İlkögrretim Online, vol. 20, no. 2, pp. 74-88, 2021, doi: 10.17051/ilkonline.2021.02.01.

[6] L. R. Octaberlina and A. I. Muslimin, "Efl students perspective towards online learning barriers and alternatives using moodle/google classroom during covid-19 pandemic," Int. J. High. Educ., vol. 9, no. 6, pp. 1-9, 2020, doi: 10.5430/ijhe.v9n6p1.

[7] M. McKenna, X. Soto-Boykin, K. Cheng, E. Haynes, A. Osorio, and J. Altshuler, "Initial Development of a National Survey on Remote Learning in Early Childhood During COVID-19: Establishing Content Validity and Reporting Successes and Barriers," Early Child. Educ. J., no. 0123456789, 2021, doi: 10.1007/s10643-02101216-y.

[8] A. M. Maatuk, E. K. Elberkawi, S. Aljawarneh, H. Rashaideh, and H. Alharbi, "The COVID-19 pandemic and E-learning: challenges and opportunities from the perspective of students and instructors," J. Comput. High. Educ., no. 0123456789, 2021, doi: 10.1007/s12528-02109274-2.

[9] L. Umaroh, "STRENGTHEN, PLAN , AND UTILIZE; EXPLORING NOVEL METHOD FOR TEACHING ENGLISH DURING PANDEMIC," vol. 4, pp. 198-202, 2021.

[10] R. Rafiola, P. Setyosari, C. Radjah, and M. Ramli, "The Effect of Learning Motivation, Self-Efficacy, and Blended Learning on Students' Achievement in The Industrial Revolution 4.0," Int. J. Emerg. Technol. Learn., vol. 15, no. 8, pp. 71-82, Apr. 2020, [Online]. Available: https://www.learntechlib.org/p/217073.

[11] E. R. Kazakoff, P. Macaruso, and P. Hook, "Efficacy of a blended learning approach to elementary school reading instruction for students who are English Learners," Educ. Technol. Res. Dev., vol. 66, no. 2, pp. 429-449, 2018, doi: 10.1007/s11423-017-9565-7.

[12] E. Munastwi, "Managing Education in the Global Pandemic: Best Strategy to Carry Out Natural Science Learning," vol. 5, no. 1, pp. 183-190, 2021.

[13] R. J. R. Wanodya, N. A. Drajati, and S. S. Tarjana, "Parents' Perceptions of Their Young Children's English LiteracyAcquisition: A Narrative Inquiry," Pedagog. J. English Lang. Teach., vol. 9, no. 1, pp. 47-58, 2021, doi: 10.32332/joelt.v9i1.3066.

[14] Kementerian Pendidikan dan Kebudayaan, Peraturan Menteri Pendidikan dan Kebudayaan Republik Indonesia Nomor 137 tahun 2013. Indonesia, 2013.

[15] N. Makaluza, "STORYTELLING FOR EARLY LITERACY DEVELOPMENT IN ISIXHOSA : A CASE STUDY OF A GRADE ONE CLASS IN THE By NOLITHA MAKALUZA A Thesis submitted in fulfilment of the requirements for the Master of Education Degree in Language and Literacy Education Supervisor:," no. January, 2018.
[16] T. Cremin, R. Flewitt, J. Swann, D. Faulkner, and N. Kucirkova, "Storytelling and story-acting: Coconstruction in action," J. Early Child. Res., vol. 16, no. 1, pp. 3-17, Dec. 2017, doi: $10.1177 / 1476718 X 17750205$.

[17] A. Gusti Ayu Putu Diah Permata Sari, "Balinese Folklore Literacy as English Learning Material at Communication Studies, STAHN Mpu Kuturan Singaraja," vol. 491, no. Ijcah, pp. 105-110, 2020, doi: 10.2991/assehr.k.201201.018.

[18] R. Kurnia, "A Culturally Relevant Picture Book for Children's Early Literacy," Ijicc.Net, vol. 14, no. 11, pp. 16-34, 2020, [Online]. Available: https://www.ijicc.net/images/Vol_14/Iss_11/14110 1_Kurnia_2020_E1_R.pdf.

[19] I. Satriani, "Storytelling in Teaching Literacy: Benefits and Challenges," English Rev. J. English Educ., vol. 8, no. 1, p. 113, 2019, doi: 10.25134/erjee.v8i1.1924.

[20] I. M. Sayer, M. Kristiawan, and M. Agustina, "Fairy Tale as a Medium for Children's Character Cooperation Building," Al-Ta lim J., vol. 25, no. 2, pp. 108-116, 2018, doi: 10.15548/jt.v25i2.458.

[21] I. P. Y. Purandina and I. M. A. Winaya, "Pendidikan Karakter di Lingkungan Keluarga Selama Pembelajaran Jarak Jauh pada Masa Pandemi COVID-19," Cetta J. Ilmu Pendidik., vol. 3, no. 2, pp. 270-290, Jun. 2020, doi: 10.37329/cetta.v3i2.454.

[22] E. Sulistianingsih, S. Jamaludin, and S. Sumartono, "Digital storytelling: a powerful tool to develop student's emotional intelligence," $J$. Curric. Indones., vol. 1, no. 2, pp. 33-40, 2018.

[23] R. Yusuf, "Teaching EFL Students Using Selected Media: Offline Video Taken From YouTube," Utamax J. Ultim. Res. Trends Educ., vol. 2, no. 1, pp. 29-33, 2020, doi: 10.31849/UTAMAX.V2I1.2909.

[24] I. P. Y. Purandina, "IMPLEMENTASI MEDIA DIGITAL UNTUK PERKEMBANGAN BAHASA INGGRIS," Prtama Widya J. Pendidik. Anak Usia Dini, vol. 6, no. 1, 2021, doi: 10.25078/pw.v6i1.2086.

[25] L. P. Puspawati and I. M. Suastika, "The Play of Cupak Gerantang in Wayang Kulit and Traditional Dramas and Values in Balinese and Sasak Society in Lombok," Proc. 2nd Int. Conf. Technol. Educ. Sci. (ICTES 2020), vol. 540, no. Ictes 2020, pp. 252-257, 2021, doi: 10.2991/assehr.k.210407.248.

[26] M. K. Adhi, "MARGINALIZATION : MESATUA BALI TRADITION INVOLVED ALPHA Hindu University of Indonesia , Denpasar - Bali , 2018 Hindu University of Indonesia , Denpasar - Bali , 2018," in Proceeding Book - International Seminar Bali Hinduism, Tradition and Interreligious Studies, 2018, pp. 377-384.

[27] Ismail, I. S. Samad, and Masnur, "The impact of interactive reading using local folktales stories in supporting students ' vocabulary achievement in Indonesian EFL learners," Majesty J., vol. 1, no. 2, 
pp. 25-37, 2019.

[28] E. M. Ratnasari, "The Influence of Picture Book to the Storytelling skill of Preschool Children," Indones. J. Early Child. Educ. Stud., vol. 9, no. 1, pp. 8-12, 2020, doi: 10.15294/ijeces.v9i1.37805.

[29] D. D. Nanda, B. Simbolon, F. A. Damanik, and Y. B. Sembiring, "Moral Value and Character Building Education in Folklore From Central Java 'Timun Mas,"' J. Lang. Lang. Teach., vol. 9, no. 1, p. 85, 2021, doi: 10.33394/jollt.v9i1.3319.

[30] R. N. Anisa, "SERIES OF NUSANTARA FOLKLORE STORYBOOKS AS THE MEDIA FOR EXTENSIVE READING FOR INDONESIA ELEMENTARY STUDENTS," vol. 2, no. December, pp. 72-76, 2019.

[31] K. Widhiyanti and S. G. Gunanto, "Nusantara Folklore in the Digital Age," SSRN Electron. J., 2021, doi: 10.2139/ssrn.3800616.

[32] J. R. Fraenkel and N. E. Wallen, Introduction to Qualitative Research: How to Design and Evaluate Research in Education, 7th ed. Boston, M.A.: McGraw-Hill, 2008.

[33] J. Gerring, Case Study Research: Principles and Practices. New York: Cambridge University Press, 2007.

[34] G. R. Asadullina, N. V. Korovkina, E. V. Sadretdinova, R. S. Badretdinovich, and N. G. Hajrullina, "Social Character: Issues of Methodology and Research Methods," Rev. Amaz. Investig., vol. 9, no. 26, pp. 545-553, 2020, doi: 10.34069/ai/2020.26.02.61.

[35] J. Heigham and R. Croker, Qualitative Research in Applied Linguistics: A Practical Introduction. New York: Palgrave Macmillan, 2009.

[36] H.-T. Hung, J. C. Yang, G. J. Hwang, H.-C. Chu, and C.-C. Wang, "A scoping review of research on digital game-based language learning," Comput. Educ., vol. 128, no. 1, pp. 89-104, 2018, doi: https://doi.org/10.1016/j.compedu.2018.07.001.

[37] U. Flick, "Triangulation in Data Collection," SAGE Res. Methods, 2018, doi: https://dx.doi.org/10.4135/9781526416070.n34.

[38] L. J. Moleong, Metodologi Penelitian Kualitatif. Bandung: PT. Remaja Rosdakarya Offset., 2013.

[39] H. Noble and R. Heale, "Triangulation in research, with examples," Evid. Based. Nurs., vol. 22, no. 3, pp. 67-68, 2019, doi: 10.1136/ebnurs-2019103145.

[40] K. Roulston, "Triangulation in qualitative research," QualPage, 2018. https:/qualpage.com/2018/01/18/triangulation-inqualitative-research/.

[41] M. B. Miles and A. M. Huberman, Qualitative Data Analysis: An Expanded Sourcebook, 2nd ed. California: SAGE Publications Inc., 1994.

[42] S. M. Renz, J. M. Carrington, and T. A. Badger, "Two Strategies for Qualitative Content Analysis: An Intramethod Approach to Triangulation," SAGE Journals, vol. 28, no. 5, pp. 824-831, 2019, doi: https://doi.org/10.1177/1049732317753586.
[43] L. Piao, "The High Lonesome Sound in Little Voices: The Use of Appalachian Balladry in the Early Childhood Classroom The High Lonesome Sound in Little Voices :," 2020. 